627

Un38t 35

GT

US Armin Corps

of Engineers
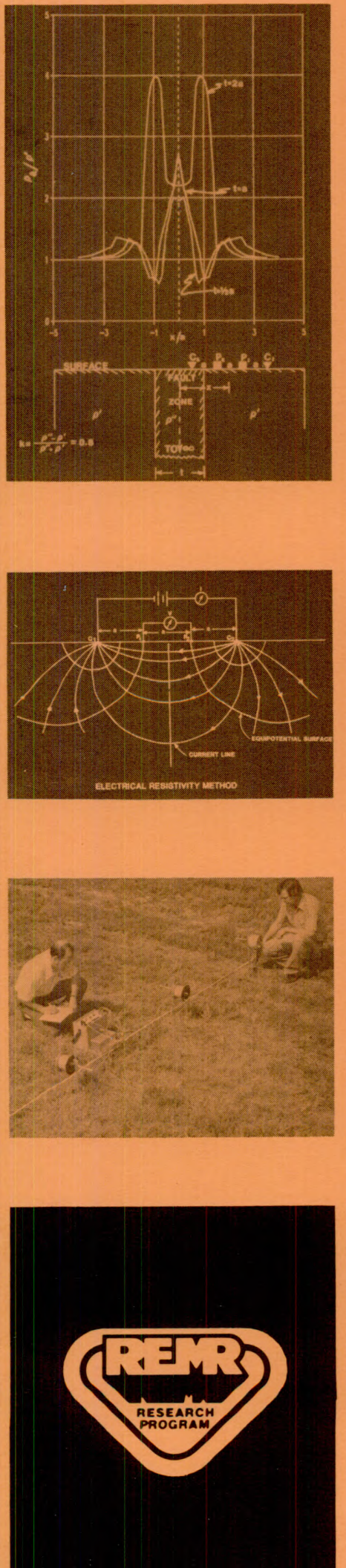

REPAIR, EVALUATION, MAINTENANCE, AND REHABILITATION RESEARCH PROGRAM

TECHNICAL REPORT REMR-GT-9

\section{A SURVEY OF ENGINEERING GEOPHYSICS CAPABILITY AND PRACTICE IN THE CORPS OF ENGINEERS}

\author{
by
}

Dwain K. Butler, Ronald E. Wahl

Geotechnical Laboratory

DEPARTMENT OF THE ARMY

Waterways Experiment Station, Corps of Engineers

PO Box 631, Vicksburg, Mississippi 39180-0631

Nolan W. R. Mitchell

Missouri River Division Laboratory

US Army Engineer Division, Missouri River

420 South 18th Street

Omaha, Nebraska 68102

and

Gregory L. Hempen

US Army Engineer District, St. Louis

210 Tucker Blvd. North

St. Louis, Missouri 63101-1986

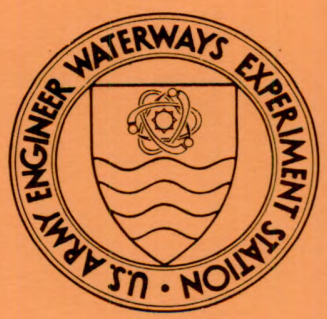

March 1988

Final Report

UNIVERSITY OF MICHIGAN

З 9015086524215

Approved For Public Release; Distribution Unlimited

Prepared for DEPARTMENT OF THE ARMY

US Army Corps of Engineers

Washington, DC 20314-1000

Under Civil Works Research Work Unit 32.315 